\title{
Bookshelf 2020
}

\author{
Richard Price and Sally Price \\ Coquina Key, Florida, USA \\ rixsal@gmail.com;www.richandsally.net
}

This has been a most trying year for book reviewers. How many of the scholars we solicited answered that the unexpected demands of remote teaching, or the obligations of home schooling, or any other unusual responsibilities caused by Covid-19 made it impossible for them to write a review? And how many reviewers balked at (while others kindly acquiesced to) the new practice of many publishers sending out review copies exclusively in digital form?

Another indicator of Covid-inspired chaos in the publishing industry? When we asked Palgrave/Springer (which publishes more of the books we review than any other publisher) to send a book, scheduled for July 2020 publication, to our reviewer, the following reply came back: "Unfortunately, ... Decoloniality and Gender in Jamaica Kincaid and Gisèle Pineau, seems to have been massively postponed; the publication date appears to be 31 May 2025."

Publishers, with warehouses closed, or open only sporadically, have generally done their best but here's a list of books that we requested (almost all for Bookshelf) but never received:

Nous n'avons pas vu passer les jours, by Simone Schwarz-Bart \& Yann Plougastel (Paris: Grasset, 2019, paper €19.00)

La Souvenance, by Ernest Pépin (Petit-Bourg, Guadeloupe: Caraïbéditions, 2019, paper $€ 17.30)$

My Time Among the Whites: Notes from an Unfinished Education, by Jennine Capó Crucet (New York: Picador, 2019, paper US\$17.00)

Ordinary Girls: A Memoir, by Jaquira Díaz (New York: Algonquin Books, 2019, cloth US\$26.95)

Saint X: A Novel, by Alexis Schaitkin (New York: Celadon Books, 2020, cloth US\$26.99)

Shame on Me: An Anatomy of Race and Belonging, by Tessa McWatt (London: Scribe UK, 2019, paper US\$17.13)

Bla_k: Essays and Interviews, by M. NourbeSe Philip (Toronto ON: Book*hug, 2017, paper US\$20.00)

Un ailleurs à soi, by Emmelie Prophète (Montreal QC: Mémoire d'encrier, 2018, paper US\$20.29)

(C) RICHARD PRICE AND SALLY PRICE, 2021 | DOI:10.1163/22134360-09501052

This is an open access article distributed under the terms of the CGG BY4 4.P license. Brill.com04/26/2023 11:03:26AM 
Dream of Europe: Selected Seminars and Interviews: 1984-1992, by Audre Lorde, edited by Mayra Rodriguez Castro (Berkeley CA: Kenning Editions, 2020, paper US\$20.00) La Finca: Love, Loss, and Laundry on a Tiny Puerto Rican Island, by Corky Parker (San Antonio TX: Trinity University Press, 2020, cloth US\$29.95)

Une semaine et un jour, by Marijosé Alie (Paris: HC Editions, 2020, paper €19.00) Afterlife, by Julia Alvarez (New York: Algonquin Books, 2020, cloth US\$25.95) Very Drunk / Borracho: Love Poems \& Other Acts of Madness / Poemas de amory otros actos de locura, by Jesús Papoleto Meléndez (New York: 2Leaf Press, 2020, paper US\$18.99)

After the Storm, by Tamara Groeneveldt (Philipsburg, St Maarten:House of Nehesi, 2019, n.p.)

Quatre-vingt-dix seconds, by Daniel Picouly (Paris: Albin Michel, 2018, paper, €19.50)

Boricua en la luna, edited by Elena M. Aponte (Philadelphia PA: Taller Puerto Rico, 2020, paper US\$9.95)

The Taste of Sugar, by Marisel Vera (New York: Liveright, 2020, cloth US\$26.95)

Ernesto: The Untold Story of Hemingway in Revolutionary Cuba, by Andrew Feldman (Brooklyn NY: Melville House, 2018, cloth US\$27.99)

This Thing That Is Not A Thing, by Paulette A. Ramsay (Kingston: University of the West Indies Press, 2020, paper US\$30.20)

Magdalen: River of Dreams: A Story of Colombia, by Wade Davis (New York: Knopf, 202O, cloth US\$30.00)

Daylight Come, by Diana McCaulay (Leeds, U.K.: Peepal Tree, 2020, paper, £9.99)

The Sea Needs No Ornament / El mar no necesita ornamento: A Bilingual Anthology of

Contemporary Caribbean Women Poets, edited by Loretta Collins Klobah \& Maria Grau Perejoan (Leeds, U.K.: Peepal Tree, 2020, paper, £14.99)

StickNo Bills, Elizabeth Walcott Hackshaw (Leeds, U.K.: Peepal Tree, 202O, paper £ 9.99) Cuba:Music and Revolution: Original Album Cover Art of Cuban Music: The Record Sleeve Designs of Revolutionary Cuba 1960-85, by Stuart Baker \& Gilles Peterson (London: Soul Jazz Books, 2021, cloth US\$39.90)

La isla de la fantasía: El colonialismo, la explotación y la traición sobre Puerto Rico, by Ed Morales (New York: Bold Type Books, 2019, paper US\$16.99)

This year, once again, we express our gratitude to all the reviewers who have, collectively, provided such a rich resource for keeping up with writing on the region. At the same time, we must lament the fact that a small number of the people who've accepted a book and promised to review it have, despite a long series of gentle reminders over a year or two, never shared their reactions to the book with NWIG readers. With our apologies to the authors of books that have not been given their due in these pages for this reason, we simply list them here. 
Writing for Inclusion: Literature, Race, and National Identity in Nineteenth-Century Cuba and the United States, by Karen Kornweibel (Vancouver BC: Fairleigh Dickinson University Press, 2018, cloth US\$9o.oo)

The Great Woman Singer: Gender and Voice in Puerto Rican Music, by Licia Fiol-Matta (Durham NC: Duke University Press, 2017, paper US\$24.95)

Indigenous Struggles for Autonomy: The Caribbean Coast of Nicaragua, edited by Luciano Baracco (Lanham MD: Lexington Books, 2019, cloth US\$95.00)

Narratives of Obeah in West Indian Literature: Moving through the Margins, by Janelle Rodriques (New York: Routledge, 2019, cloth US\$140.00)

Santeria, Vodou and Resistance in Caribbean Literature:Daughters of the Spirits, by Paul Humphrey (London: Legenda, 2019, cloth US\$99.00)

We begin our mini-reviews, as is our custom, with fiction.

Jamaica-born, Queens-raised Maisy Card's debut novel, These Ghosts Are Family (New York: Simon \& Schuster, 2020, cloth US\$26.00) comes with scintillating blurbs from publications as diverse as Ms., Booklist, and Kirkus Reviews. We found it somewhat less magical, though its intergenerational sweep is certainly ambitious and the local dialect nicely tuned-Jamaicans who moved to Brooklyn and Harlem, seen back home in the 196os and then in their later American years, as well as slave-era ancestors who live in the horror-space of a Thomas Thistlewood-like plantation, appear in disjointed chapters that read as if written on separate occasions, never quite hanging together. The writing also varies, from memorable to mundane. Perhaps readers should judge for themselves whether, as Publishers Weekly claimed, "This masterful chronicle haunts like the work of Marlon James and hits just as hard" —or not.

In Jamaica-born Donna Hemans's second novel, Tea by the Sea (Pasadena CA: Red Hen Press, 2020, paper US\$16.95), a girl is raised by her father, who stole her from a rural Jamaica maternity ward at birth, and isn't reunited with her mother, who has searched for her incessantly, until the end of the book, 17 years later. The plot is fast moving, the writing less "soaring" than the almost inevitable blurb by Marlon James suggests (he seems to offer his imprimatur to much of the Jamaica-related writing we review in these pages), but overall, a good read that captures the flavors and family relations of both rural Jamaica and Jamaicans in Brooklyn.

Queenie (New York: Scout, 2019, paper US\$16.oo), the prize-winning debut novel by Candice Carty-Williams, a Black British author of Jamaican heritage, seems to be aimed at millennial, female readers. It's filled with texting, sex, dates, girl-talk, and discussions of hair care, shoes, and clothes, as well as Blackness and racism. Not our cuppa.

Frying Plantain, by Zalika Reid-Benta (Toronto ON: House of Anancy, 202O, paper US\$16.95), is an engaging, enjoyable debut novel, a series of vignettes 
narrated by a girl of Jamaican parentage in Toronto, as we see her growing from the age of ten to twenty. In her mostly-Black grade school, she worries that she has "the weakest accent of all the Canadian-borns" and frets with her friends about how the snow messes their hair: "the frizz come out, kinky and tight, disrupting the silkiness they'd endured the hot comb for the night before." As she moves through her teenage experiences, the constants are her rocky but loving relations with her strict mother, the often-comic difficulties she witnesses between her immigrant Bible-toting grandmother and her stillgallivanting grandfather, and the frequency of well-tuned Jamaican-Canadian speech. It's a convincing and affectionate look into Toronto's Little Jamaica, a book to remember.

Jamaica-born, Paris-based Alecia McKenzie, whose previous books have won prizes, now offers up A Million Aunties (Brooklyn NY: Akashic, 2020, US\$15.95), a wide-ranging novel told in several voices that moves between New York, rural Jamaica, and Paris. Painting is at the heart of the book but so is family, love, heartbreak, and loss. The story pulls you in and holds you right till the end. It's strongly written with a delicate touch.

The Confessions of Frannie Langton (New York: Harper, 2019, cloth US\$ 26.99), by Jamaica-born, Cayman raised, London lawyer and author Sara Collins, is a memorable debut novel. Marketed as a gothic mystery, this confession combines slave narrative, love story, and crime novel, beginning in Jamaica, where "mulatta" Frannie is raised as a house servant and, on a bet, taught to read, write, and assist her partially deranged master/father/rapist in his pseudo-scientific, Mengele-like experiments about racial difference. When the plantation burns down, she is given as a gift to a London scientist of the same ilk, falls in love with his French, laudanum-addicted wife, is turned out and finds herself working in a flagellation brothel, and - as the novel opens and closes-is on trial in the Old Bailey for murdering the scientist and his wife. It's a real page-turner and, for us, it really works.

In Still Life (New York: The New Press, 2020, cloth US\$25.99), award-winning South African writer Zoë Wicomb, who lives in Scotland, has produced a thought-provoking novel. Among the spectral creatures that haunt the narrator in the opening pages of this extraordinary work, set in Scotland, Cape Town, and London, is Mary Prince, whose famous nineteenth-century (dictated) autobiography was subtitled "A West Indian Slave." The plot involves the narrator, a writer who is supposed to write a biography of long-forgotten Scottish poet and abolitionist Thomas Pringle, whose only real legacy is in South Africa, where he lived briefly but is still remembered as "the Father of South African Poetry." Finding herself unequal to the task her literary agent has set for her, she finds help from the specters of Mary (whose autobiography was 
published by Pringle), Hinza (a Motswana boy who was adopted by Pringle), and Sir Nicholas Green, whom she exhumes from the pages of Virginia Woolf's Orlando. This complex book delicately and persuasively explores questions of race, slavery, history, memory, and authorship.

Love After Love (New York: One World, 2020, cloth US\$27.00) is Ingrid Persaud's wonderful debut novel, overflowing with Trinidad speech and daily life, told in the voices of three memorable characters who lime, fete, love, and suffer with one another. Gossip, cooking, violence, and sex make you laugh and, at times, almost cry. Marlon James's blurb calls this "the most electrifying prose you will read all year" and, particularly in terms of its dialogue, we concur. Love After Love is a winner.

In The Frequency of Magic (Leeds, U.K.: Peepal Tree Press 2019, paper £12.99), by Trinidad-born, London-based Anthony Joseph, the author's alter-ego, a butcher named Raphael, has spent 41 years struggling to complete a novel called "The Frequency of Magic"-100 chapters, each exactly 10oo words long (just like the book itself). Raphael "knew that words should be allowed to land where they would land, and would not be subsumed by fixed meaning, that poetry created meaning in the gaps of language." His characters-young Luke, the Great Bandit, the actress Emma, the musician, and so many others-slip in and out of his grasp, fighting to maintain control of their own destinies, sometimes even sneaking into his house to check what's being said about them in the book. As in Joseph's Kitch: A Fictional Biography of a Calypso Icon (which we called our favorite novel of 2018 in Bookshelf for that year), the vernacular is magical, silky poetry mixed with grit, village scenes where the manicou and agouti roam, real folks talking, trying by lying to get visas and sometimes surviving in overseas, and always music (some calypso and pan, much jazz). Trini to the core, with fantastic riffs, nothing quite like it: the characters wondering aloud what will happen to them next or, as one protests when he discovers that the book is on its final page: "Dead you say? Dead what? Dead who? Well, brother, tell them that when fish clap, I swim, but no axe of narrative make by man or woman can bind me in no textology. Ah going in he mother cunt!"

One Year of Ugly (New York: 37 Ink, 2020, paper US\$26.oo), the debut novel of Trinidadian short-story writer Caroline Mackenzie, takes readers into the world of "illegal" Venezuelan refugees in 2016 Trinidad. The narrative moves swiftly and keeps one turning the pages, the prose seems aimed at a female readership, and there's lots of sex and crime as well as laughter. But it is also about family and the ways people sticking together manage to survive. Hardly great literature, but it's good entertainment and rings true about many aspects of life in contemporary Venezuela and Trinidad. We could imagine watching it as a popular movie series on $\mathrm{TV}$. 
Book of the Little Axe, by Lauren Francis-Sharma (New York: Grove Atlantic/ Atlantic Monthly Press, 2020, cloth US\$26.00), is an ambitious, expansive historical novel that tacks between late eighteenth- and early nineteenth-century Trinidad and the contemporaneous world of the Apsáalooke (Crow Nation) in what is today Montana. The book's Trinidad is caught between the Spanish, French, and invading British while its Northwest America is peopled by rival Indigenous groups and advancing, often half-breed, scouts and settlers. Multiple characters, a tangled plot, and experiments in narration (the use of a found diary) add up to a sometimes overrich mix. Complex and multiple identities become central-slave and free, Black, White and Indigenous, FrenchCanadian, American, and more-in a story set in a tumultuous time, both in the Caribbean and the Great Northwest.

In The Mermaid of Black Conch (Leeds, U.K.: Peepal Tree Press, 202O, paper $£$ 9.99), Monique Roffey, Trinidad-born British author of the acclaimed The White Woman on the Green Bicycle (2009), has written a remarkable, fairy-talelike story of a beautiful Taino girl, cursed by jealous wives to become a mermaid and to swim the seas for centuries, who is entranced by a modern-day smallisland fisherman singing with a guitar in his pirogue. Experiencing adventures on shore as she slowly turns back into a woman, her life and that of her host village will never be the same. An affecting, beautiful novella, truly memorable. In January 2021, Mermaid was chosen for the $2020 £_{30,000}$ Costa book-of-theyear award.

Unlike Trinidad-born Canadian novelist Shani Mootoo's Moving Forward Sideways like a Crab, which (we said in "Bookshelf 2017") was marked by "vivid descriptions of the landscape and social world of Trinidad," her Polar Vortex (Brooklyn: Akashic, 2020, paper US\$16.95) is set in wintry rural Ontario. Like the earlier novel, it is "a strong story of sexual identities, and love." But here, a married lesbian couple (one an Indo-Trini immigrant) deals with ongoing secrets and jealousies and the sudden intrusion of a former male friend (a Ugandan Indian immigrant) from one of their pasts, leading to unexpected consequences.

Dominoes at the Crossroads, by Kaie Kellough (Montreal QC: Véhicule Press, 2020 , US\$19.95), is a collection of short-story riffs, some narrated by a tenorsax player who is touring the bleak Canadian provinces, others by a Montreal teenager of Haitian parentage, yet others by a Calgary high-schooler with parents from Guyana (like those of the Canadian-born author himself). Varied characters - student radicals, poets, secret agents, hitchhiking teenagersswirl through mostly Canadian cities and towns, though Paris and Georgetown appear too, and issues of race and slavery, the legacies of colonialism, and the harsh realities of Canadian winters mix with frequent sounds of jazz. Experimental writing that is lively and inventive. 
The Summer Country (New York: William Morrow, 2019, cloth US\$26.99), by Lauren Willig, "author of the New York Times bestselling Pink Carnation series and a RITA Award-winner for Best Regency Historical," is a historical novel set on two nineteenth-century Barbados plantations, "a sweeping, dramatic epic of lost love, lies, jealousy, and rebellion" (according to its jacket). Despite the author's degrees in history (Yale, Harvard) and her diligent background reading of relevant scholarly books on the period, this tale of the leadup to Bussa's 1816 Rebellion and its postemancipation aftermath in 1854 fell rather flat for us. Perhaps it's our distaste for the genre, perhaps it's our irritation at this outsider's view-almost as if this is Downton Abbey set in the colonial Caribbean.

Black Rain Falling, by Jacob Ross (London: Sphere, 2020, cloth £14.99), follows his acclaimed The Bone Readers (which we called "a compelling read" in "Bookshelf 2016") as the second in a trilogy of crime novels set in his native Grenada (which he calls by its aboriginal name Camaho, just as he calls Carriacou Karo Island). His protagonist, detective Michael "Digger" Digson, and sidekick Miss Stanislaus, as in the earlier book, get embroiled in a series of killings, rapes, and drug arrests that take them all over the island, from the forested mountains to the beaches and on to Karo Island, whose female-run world is shown to be culturally distinct from that of Camaho. Rich local color, a plot that speeds along, fine character development, a dose of humor. What more could one ask? This is a literary detective novel to be savored.

Tentacle (Sheffield, U.K.: And Other Stories, 2018, paper US $\$ 13.95$ ), by Dominican music composer, singer (merengue), and author Rita Indiana (who now lives in Puerto Rico), is set in postapocalyptic D.R., where environmentalism meets seventeenth-century buccaneers, queer politics meets contemporary art and Santería, and drugs and sex abound. In his blurb, Junot Díaz calls it "an unforgettable experience," which pretty much sums it up. (The 2015 Spanish original, La mucama de Omicunlé, won the biennial Grand Prize for Literature of the Association of Writers of the Caribbean.) Indiana's Made in Saturn (Sheffield, U.K.: And Other Stories, 2020, paper US\$15.95), which follows, is more of a hyperrealist novel in which a former artist and heroin addict antihero, sent for detox to Havana by his once-revolutionary father who is now part of the D.R.'s ruling elite, spends the first half of the story in Havana, where he explores some of the seedier sides of the capital, before returning to Santo Domingo, where he tries to reintegrate himself into that city's lively but differently corrupt world. This is writing that keeps you reading, with an underlying message about the unfortunate afterlife of Caribbean revolutions. And the ghost of Goya haunts both books.

In the Dream House (Minneapolis MN: Graywolf Press, 2019, cloth US\$26.oo), by American writer Carmen Maria Machado, is a literary memoir. 
Set mainly in the Midwest when she was in her twenties, it is written as an innovative series of kaleidoscopic vignettes recounting her inexorable descent into a psychologically abusive relationship with another woman. "I enter into the archive that domestic abuse between partners who share a gender identity is both possible and not uncommon, and that it can look something like this." There is a page-and-a-half near the end evoking a visit to Santa Clara, Cuba, the birthplace of her paternal grandfather, but otherwise the Caribbean is absent from this often riveting, horrifying, sexually explicit work.

The back cover of The Fallen, by short-story writer and journalist Carlos Manuel Álvarez, describes his book as a "portrait of family life in Cuba." And the flap of My Favorite Girlfriend was a French Bulldog, by poet/fiction writer/playwright Legna Rodríguez Iglesias, glosses hers as "a multigenerational portrait of her native Cuba." These two books also share their organization (several-page chapters, in varying voices) and shortness (143 and 204 pages, though frequent blanks bring the actual texts down to 129 and 168). But there the similarity ends. The Fallen (Minneapolis MN: Graywolf Press, 2020, paper US\$16.oo) is the English translation by Frank Wynne of Los Caídos, a debut novel, structured as a series of reflections on life by the mother, father, son, and daughter in a Cuban family. The publisher's assertion that it charts the disintegration of the family and a "clash between the ardent idealism of the old guard with the jaded pragmatism of the young" is true but, in our opinion, doesn't capture the subtlety and complexity of the four voices, each confronting a different set of existential challenges of life in near-contemporary Cuba. This is very strong writing, moving and thoughtful. My Favorite Girlfriend was a French Bulldog (San Francisco: McSweeney's Publishing, 2020, paper US\$22.00), translated by Megan McDowell, leans more toward the poetic [surreal?], each of its 15 chapters narrated by a not-always-identified voice (though the final one is clear, and helps to explain the book's title), and explores interior lives, without much explicit connection to Cuba.

Maryse Condé's twelfth novel, The Belle Créole (Charlottesville: University of Virginia Press, 2020, paper US\$21.95), was published in French in 2001 and now appears in a lively translation by Nicole Simek, with a useful afterword by Dawn Fulton. Like Condé's earlier Crossing the Mangrove, but unlike many of her other works, it is firmly set in Guadeloupe and displays the multiple ambivalences (and mix of affection and bitterness) she feels about her native land. As usual, ironies abound — at the story's outset, a nymphomaniacal béké woman is murdered by Dieudonné, her young, black gardener/lover, who is acquitted in court with the help of a lawyer who uses "a line of argument which he deemed Césairean or even Fanonian.” The protagonist is then followed, moving through a society that is violent (muggings, rapes), stench-ridden, filled with packs of 
marauding dogs, and in the midst of labor strikes and doomed-to-fail independence politics (with the 1999 strikes she describes presaging the even larger ones that rocked Guadeloupe a decade later, to similar noneffect). Condé's view of Guadeloupe couldn't be farther from the French or American gaze of a tropical paradise. Proudly politically-incorrect and cynical as ever, she unfolds for us her fierce, cosmopolitan, and unvarnished vision of the world.

The Wondrous and Tragic Life of Ivan and Ivana (New York: World Editions, 2020, paper US\$16.99) is the inimitable Maryse Condés latest novel (French original, 2017), praised by Junot Díaz, Edwidge Danticat, Henry Louis Gates, Jr., Angela Davis, and others. Condé writes that "we were raised with the prospect that the world would gradually improve ... That consequences of colonialism, racism, and intolerance would disappear ... Today, we realize in amazement that nothing of the sort has happened and that the world has become an incomprehensible, blood-stained enigma." That, she says, is the background to this tale, which begins with twins born poor in Guadeloupe, follows them to Mali (a country where Condé spent years), and thence to Paris and its banlieues. Over the course of the book, the nearly incestuous twins go their separate ways, with the boy as a converted jihadist finally killing his sister in a Bataclan-like terrorist attack. Winner of the 2018 Alternative Nobel Prize in Literature, Condé remains a supreme spinner of tales and a bitter commentator on the world in which we live. (We wish that her devoted husband-translator, Richard Philcox would render her oft-mentioned "Guyane" as "French Guiana" rather than "Guyana," since it detracts from her mordant commentaries on French colonialism in the Caribbean.)

Humus (Charlottesville: University of Virginia Press 2020, paper US\$29.50) is Fabienne Kanor's moving story of 14 women who in 1774 leapt overboard from the slave ship Le Soleil, into the shark-infested waves rather than submit to enslavement. Restoring the humanity to what the captain lamented as "lost cargo," she imagines each of their lives through freedom and captivity, in village settings and grueling treks to the coast, in moments of tenderness and scenes of absolute horror. The writing is poetic — at once lyrical and muscular, ephemeral and raw-a memorable read. The ten-page afterword by Gladys M. Francis follows Kanor, who was born in France of Martiniquan parents, from archives in Nantes to travels through multiple parts of Africa, and on to the composition of the text, in which "each word was spoken aloud before setting it down in ink." This English edition is a translation by Lynn E. Palermo in collaboration with Kanor of the original French novel published by Gallimard in 2006.

Zo (New York: Knopf, 202O, cloth US\$26.95) is the beautiful debut novel by Xander Miller, a White American medical technician who volunteered after the 2010 earthquake and married a Haitian nurse. Written in the form of a fable, but 
with rich local characters, geographical specificity, and effective use of Haitian Creole, it centers on a love story between a poor orphan $(\mathrm{Zo})$ and the daughter of a wealthy Haitian doctor, taking the protagonists from the countryside to the capital and eventually through the nightmare of the earthquake and the cholera outbreak. We found the book dreamlike, moving, wonderfully written, and impressively true to Haitian realities. The long section evoking the Goudougoudou is among the most persuasive descriptions of the event that we've ever read.

My Mother's House (New York: Knopf, 2020, cloth US\$26.95), the debut novel of Haiti-born U.S. writer Francesca Momplaisir, explores the power of evil and depravity among everyday immigrants in South Ozone Park, Queens. The Haitian protagonists - poor, striving men and women (taxi drivers, hairdressers, artists) - fall prey to a slick sexual predator who immigrated in his twenties. Written in part in the object-narrative style popular in the eighteenthcentury, this book has the House (La Kay) telling much of the tale of the oftenawful goings-on within the secret "safe-room" just off its basement. The book effectively captures the desperate efforts and feelings of being at the bottom of New York's social ladder. It is a dark but compelling read.

The Immortals (Albany: SUNY Press, 2020, paper US\$18.95) is prize-winning Haitian writer Makenzy Orcel's debut novel (Les immortelles, 2010), sensitively translated into English by Nathan H. Dize. In previous Bookshelf reviews, we noted that Orcel's L'Ombre animale (2016) "opens in the voice of a female cadaver, who narrates throughout 335 pages without benefit of a single period" and that his Maître-Minuit (2018) "astounds again" in evoking "the lived realities of Haiti in the second half of the twentieth century." Here, Orcel has a Port-auPrince sex worker persuading one of her clients, a writer, to record her vivid reflections on her own days whoring and those of her friends and co-workers who were killed in the 2010 earthquake-Fedna the Blowjob Queen, who loved Latin American soap operas, Géralda Huge-Tits, who was a devotee of Vodou, and most of all the narrator's prodigy Shakira, the Little Girl who loved literature, especially that of Jacques Stephen Alexis, and whose mother peddled Bibles. Her thoughts are printed in five- or eight-line fragments that leave most of each page blank. It's a moving memorial to a diverse cast of women, whose hopes, desires, needs, and wishes are no longer silenced.

Black Shack Alley, by Joseph Zobel (New York: Penguin Classics, 2020, paper US\$17.00) is the republication of Keith Warner's 1980 translation of La Rue Cases-Nègres, with the only addition being a seven-page fairly innocuous foreword by Patrick Chamoiseau that curiously employs the term "negro" (lowercase), claims that "Zobel wrote this text only a few decades after the abolition of slavery" (Martinique abolition was in 1848 and Zobel finished this autobio- 
graphical novel in 1950), and includes an undecipherable sentence on its first page. Eating lunch with us in Anses d'Arlet around 1990, Zobel said he was pleased to have the book out in English at last, though for us it reads better in French. Either way, it remains a real classic, a Martiniquan interwar comingof-age story comparable (in subject if not literary quality) to Lamming's In the Castle of my Skin. In 1983 it was made into Martiniquan Euzhan Palcy's memorable film, "Sugar Cane Alley."

Penguin Classics has also republished the inimitable Sam Selvon's The Housing Lark (2020, paper US $\$ 15.00$ ), first published 55 years ago. Its characters are what Caryl Phillips in his introduction calls "postnostalgia migrants" in London (in contrast to the more recent immigrants in, for example, The Lonely Londoners), people who are there to stay but still struggling to find suitable housing amid rampant discrimination. Its opening lines are classic Selvon: "But is no use dreaming. Is no use lying down there on your backside and watching the wallpaper, as if you expect the wall to crack open and money come pouring out, a nice woman, a house to live in, food, cigarettes, rum." So, the quixotic housing scheme is born among a small group of immigrant West Indian men, who need eventually to be rescued from their misbehavior by three West Indian women. Flat-out humor, irony, and a healthy dose of sociological truth. The dialect writing brings frequent smiles and more than occasional belly-laughs.

On to poetry.

Epiphaneia (London: Out-Spoken Press, 2019, paper US\$20.24), by Richard Georges, who was born in Trinidad and raised on Tortola where he lives, follows his strong 2017 collection, Make us all Islands (see "Bookshelf 2017") with elegiac reflections on the aftermath of devastating Hurricane Irma. Ancestors, children, twisted trees, the ruins of houses, and always the sea are everpresent in these transcendental musings. The poems are uplifting and thought provoking, even in the wake of tragedy evoking "this gorgeous too full life." The book won the 2020 осм Bocas prize for Caribbean Literature, whose distinguished judges included Earl Lovelace, Bridget Brereton, Barbara Lalla, and Laurence Breiner.

Trinidad-born, Brooklyn resident Mervyn Taylor (of whose poetic work Walcott said "Taylor's is a quiet voice ... a tone that keeps him separate and unique") has gifted us two 2020 collections, Country of Warm Snow (Swindon, U.K.: Shearsman Books, 2020, paper US $\$ 18.00$ ) and News of the Living: Corona Poems (Frankfurt KY: Broadstone Books, 2020, paper US\$18.00). We were quickly won over by the narratives in Country, the ways that these one-page-long poems capture and evoke a moment, a relationship, a scene. Take "Status," about a Flatbush tailor from Conakry: "The space where he sews / is like a cupboard, his four countrymen / squeezed in behind him. We ... talk about these / new 
immigration laws ... / I have no idea / what his status is. I only know that when / I stand before the mirror, my old suit / looks new, and that I would hide him / in my house, and feed him whatever / kind of soup it is they eat over there." Many of the poems are set in Trinidad, with calypso, carnival, and everyday street life springing to the fore, perhaps quietly as Walcott says, but always with the force of truth, catching the moment. The Corona poems-"this is the dying season"-seem less studied: lockdowns, nostalgia for normalcy, tragedy, and grieving. And a final ode for a man named George: "An asteroid aimed for the earth / did not miss this time, opened a hole / in the heart of Minnesota, that lies / smoking like a barbecue pit on the / Fourth of July."

Kaie Kellough (see his Dominoes, above) has won Canada's prestigious Griffin Poetry Prize for his third collection of poetry, Magnetic Equator (Toronto ON: McClelland \& Stewart, 2019, paper US\$16.95). From the opening pagespread of Brathwaite-inspired tidelectic "kaieteur falls" through poems describing growing up on the Canadian prairies, Kellough invokes in-betweenness: " $i$ hold a hyphen between my fingers" ... "flocks of vowels and consonants migrating along the creole/continuum, from one grammar into another" ... "perhaps arawak, perhaps Indian, perhaps portuguese, perhaps english, I don't know." A sense of mixture and question marks about ancestral Guyana: "people arrived from portugal. people arrived from africa. people arrived from india. people arrived from england. people arrived from china. people predated arrival. people fled predation. people were arrayed. people populated. whips patterned rays into people. people arose. people rayed outward to toronto, london, boo York." But also political realities amidst the liana-draped Wilson Harris-inspired forest interiors: "the would-be dictator's bomb that opened a hole in rodney" ... "the bomb his men rigged/to blow rodney silent" and "walking the seawall ... returning after 30 years ... an exxon rig crouches offshore." These serious, singing poems deserve a wide audience.

Passport to Here and There, by Grace Nichols (Hexham, Northumberland, U.K.: Bloodaxe, paper, US\$15.49), offers poems that evoke a childhood in the waterlogged spaces of Demerara, then the pleasures of her adopted Essex countryside, and finally a return after many years to Georgetown and reunion with her family and the below-sea-level places she's known. Then, the gift of a group of poems about the recent/contemporary, from Grenfell Towers to the passing of Derek Walcott and Martin Carter. Overall, strong and steady writing, honest and deep.

Pierrot (Leeds, U.K.: Peepal Tree Press 2019, paper £ 9.99) is the ninth collection by the much-anthologized St. Lucian poet, journalist, and librarian John Robert Lees. As we wrote in "Bookshelf 2017" (about his Collected Poems 19752015), his work displays "Walcottian cadences, mature, stately, controlled." Pier- 
rot, the carnival figure, emerges as "clown prince, celebratory idiot," critic of "mamaguy kaiso politricks," and "beloved masquerader ... signature of death's humanity." There are evocations of Lucian places-Pigeon Island, Balata, Becune Point-, homages to friends, artists, and poets (the passing of his friend Derek Walcott is accompanied by "the mourning bassoon of wood doves"), and he often decries the changes he witnesses ("This town [Castries] posing as a city for tourist boats / taller than Morne Pavée"). But with irony and humor he also tries, as in his poem on the possibility of a politically united St. Martin/Sint Maarten, to "bridge the points between archived nostalgia and relentless vague desire" or, with reference to police brutality in the United States and race prejudice in general, emits plaintive cries for justice: "Who made me a stranger in my world? / Who determined I was a minority?" Reflecting on reaching the age of 70, the loss of so many friends, and the state of the world, he ends by writing starkly "I wish I could say ... that everything go be okay." This is a collection to be savored.

In Marvin Thompson's Road Trip (Leeds, U.K.: Peepal Tree Press 2019, paper $£$ 9.99), his debut collection, this Black British poet, living in Wales, questions his identity: "my confusion: / born in London / was I English / like school's / niggers out / graffiti? / Did my parents / make me Jamaican?" Concerned about the ways his Mixed Race children fit in- "Will Britain learn to love my children's melanin?" - he writes poems with titles such as "Whilst Searching for Anansi with my Mixed Race Children in the Blaen Bran Community Woodland." Throughout the collection, which features some inventive stories, hangs the legacy of colonialism and empire, sometimes evoking anger, sometimes a quizzical questioning.

In The Selected Works of Audre Lorde (New York: Norton, 2020, paper US\$16.95), editor Roxane Gay, well-known feminist writer of Haitian descent, presents a representative selection from Lorde's 11 volumes of poetry and five works of prose. The first half of the book is comprised of prose written between 1977 and 1990, the second of poetry published between 1968 and 1993 (a year after Lorde's death, while she was New York State Poet laureate). New York-born Lorde, whose father was from Barbados and mother from Carriacou, described herself as "black, lesbian, mother, warrior, poet," and her writings concern the civil rights struggle, feminism, her identity as a gay Black woman, eroticism and, especially after her cancer diagnosis, illness and disability. During her final decade, some of it spent in Berlin, she had a strong influence on the developing Afro-German movement, but her writings range more widely geographically, all across the United States and from Switzerland to St. Croix. Both her prose and her poetry often startle-angry, cutting, provocative, but also surprisingly lyrical. This is an outstanding anthology. 
In her debut collection, Guabancex (London and Trafalgar, Dominica: Papillote Press, 2020, paper £6.50), named after the Taino supreme female spiritual being associated with natural destructive forces, Celia A. Sorhaindo recounts the devastation that Category 5 Hurricane Maria (2017) wreaked on her native Dominica. In the opening poem, she writes that "words will never carry you to what its like actually lets just leave it like that words cannot ever take you there at all." But she goes on to offer us a cascade of words, from her grandmother surveying the damage "mouth and eyes wide black holes of disbelief," lots on the storm's aftermath, from trying to get tarps, roof screws, galvanize, or a simple bucket of water, to the final poem, "Hurricane PraXis (Xorcising Maria Xperience)," which over a nine-page stretch provides a list of the feelings and emotions of her countrymen in the wake of the fury of Guabancex.

Prize-winning Puerto Rican/New York poet Vincent Toro offers up Tertulia (New York: Penguin, 2020, paper US\$20.00), examining everything from Hurricane María to his bis-abuela's rebellion in a nursing home, from schoolrooms to discos and films. Some of these poems go over our heads-we do not possess the Latinx cultural capital to fully enter them. Others force reflection on race, colonialism, immigration, and social justice. Yet others made us laugh out loud. In all, an explosion of interesting, stimulating work.

And then there's miscellaneous nonfiction:

The Cubans: Ordinary Lives in Extraordinary Times (New York: Viking, 202O, cloth US $\$ 28.00$ ) is by Anthony DePalma, for many years the New York Times correspondent in Cuba and married to a woman brought by her grandmother to the United States as a girl in 1960. Focusing on Guanabacoa, just across the bay from central Havana, DePalma spent three years putting together this fiction-style work, weaving together the stories of various neighborhood residents whom he interviewed for the project. Replete with quotations (as if in a novel—he claims they are based on what people told him they heard), the book recounts intertwined life histories that include travel to Ukraine, Russia, and the United States, the awful story of the 1994 tugboat-ramming that killed ${ }_{37}$ Cubans who were trying to flee, and an overall picture of Cuba as a country in shambles (economically, ideologically, bureaucratically) but with people who are endlessly adaptable and ultimately survivors. At times, DePalma expresses an almost traditional Miami view of the Revolution and its effects, though he combines it with a genuine admiration for common peoples' humanity. Overall, his characters are believable and reveal much about the uncertainties of Cuba's future.

Orwell in Cuba: How '1984' Came to Be Published in Castro's Twilight (Vancouver BC: Talonbooks, 2020, paper US \$19.95), by Québecois journalist Frédérick Lavoie, was originally published in French in 2018. It describes his two-year- 
long quest, including three several-week-long trips to Cuba, to unravel the mystery evoked in the title. He never quite succeeds in solving the puzzle but, along the way, has many adventures with Cuban writers, publishers, and other denizens of Havana and, throughout, compares Orwell's fictional totalitarian world with that built by Fidel. Much of his criticism of life since the Revolution will be familiar to readers of this journal; he even includes interviews with exiles in Miami's Little Havana. But there are enough interesting encounters to make the book worth a read by anyone hungry for information about everyday life, politics, and the literary world in Cuba today.

Photographer Magdalena Solé, born in Spain, raised in Switzerland, living in New York, fell in love with Cuba when she first visited the island in 2011. In Cuba hasta siempre (Jackson: University Press of Mississippi, 2020, cloth US \$ 50.00, with a foreword by Pico Iyer), she presents some 200 full-page color photographs taken 2011-18 - people (shopping, exercising, hanging out, dancing, playing ...), animals (some as pets, some as food), streets and houses (inside and out), with a final group capturing Cubans' reactions to Fidel's death in 2016. Altogether, a truly stunning homage to the island.

Portraits of Cuba, by Daniel Duncan, Marcela Vásquez-León \& Dereka Rushbrook (Gainesville: University Press of Florida, 2020, cloth US\$34.95), differs from Cuba hasta siempre in its photos by Duncan being somewhat more Havana-centric and less in the mode of art photography, and with a good deal more text, written by an anthropologist and geographer, that centers on $e l$ bloqueo - the 6o-year old strangle-hold the United States has imposed on the island nation — and its consequences. Throughout, the remarkable resilience of the Cuban people is emphasized. The layout looks more like a magazine than a photography book.

Cuba: Memories of Travel / Recuerdos de Viaje, by José A. Gelabert-Navia (Miami: University of Miami School of Architecture / Hong Kong: Oscar Riera Ojeda Publishers, 2020, cloth US\$55.00), comes in a handsome box along with a set of five frameable prints taken from this book of drawings made by the Havana-born author, exiled as a child to the United States, for 40 years a professor of architecture in Miami and, in 2016, on his first visit in $5^{6}$ years to his birthplace. Brief essays by the artist, Felicia Chateloin, Victor Deupi, and Alan West-Durán, published in English and Spanish, complement the evocative felt-tip-on-paper drawings of buildings around the capital, in this elegantly produced poetic and artistic act of remembrance and homage.

Inspired by Cuba: A Survey of Cuba-themed Ceramics (Gainesville FL: LibraryPress@UF, 2019, paper US\$34.95) displays a surprising array of largely upperclass dishware (mostly dinner plates and serving platters but a variety of other forms) that intrepid collector Emilio Cueto found on one of his many research 
trips around the world and had photographed by Julio Larramendi. Whether depicting "typical" Cuban scenes or vistas, Havana's coat-of-arms, Teddy Roosevelt as Rough Rider, Bacardi advertisements, or political propaganda (such as a dinner plate inscribed "PAZ TRABAJO Y PROGRESO CON BATISTA PRESIDENTE"), this is a remarkable collection for anyone interested in that sort of thing.

In An Archipelago of Caribbean Masks (Kingston: Ian Randle, 2019, paper US\$ 40.00), UPR Professor (as well as mask maker, performer, and collector) Lowell Fiet has put together a rich introduction to masks and the celebrations in which they come alive throughout the Caribbean. The stunning color photographs in this large format, 93-page book are contextualized by discussion of theoretical literature (including Lévi-Strauss on Northwest Coast Indian masking traditions) and local masking practices on different islands of the Caribbean.

Nicholas Rogers, an historian at York University until his recent retirement, has written a microhistory, Murder on the Middle Passage: The Trial of Captain Kimber (Martlesham, Suffolk, U.K.: Boydell, 2020, paper US\$24.95) that takes off from the trial of the captain of a slave ship accused of murdering a young girl ("No-name"). He paints a picture, simultaneously broad and fine-grained, of the politics of slavery and abolitionism in late eighteenth-century Britain, with special attention to the cruelties inflicted on the enslaved during their transportation across the Atlantic. Written in accessible prose (with scholarly notes and references making up the final 70-odd pages), the story reminds us that a legal system in which everything from jury selection to media coverage to final verdict can be infected by political agendas, personal loyalties and greed, religious affiliations, and contorted truths was not an invention of the Trump-era United States.

Intimations: Six Essays (New York: Penguin, 2020, paper US\$10.95), by Black British novelist Zadie Smith, who teaches at NYU, is a slim book of interesting musings written during Covid- and Trump-inflected times; it hardly mentions her Jamaican heritage.

Andre Bagoo, Trinidadian poet and short-story writer, has gathered a series of essays in The Undiscovered Country (Leeds, U.K.: Peepal Tree, 2020, paper $£$ 12.99). Ranging from thoughts about local foods like pone and doubles to interesting ruminations about writers - notably Naipaul and Walcott but also Ishion Hutchinson and other contemporary poets—and moving into historical as well as current British and Trini politics, Bagoo offers a good deal of stimulation. As he writes, he holds little back and his gay, East Indian background is always present, but it's the relevance and perspicacity of his thoughts about the world that shine brightly through. 
Riff: The Shake Keane Story, by St Vincent-born Philip Nanton (London and Roseau, Dominica: Papillotte, 2020, paper US\$19.95), is a biography of Vincentian-born Shake Keane (1927-97) - jazzman, poet, and lifelong wanderer through London, Germany, Norway, and New York. Keane left his colonial homeland in his mid-twenties and returned to a more politically sovereign island in his mid-forties, having spent the interim in London and elsewhere in Europe. After eight somewhat disappointing and frustrating years back in St Vincent, as a civil servant and teacher, he again migrated, this time to live the final 16 years of his life in Brooklyn. Nanton argues that three currentsnationalism, migration, and masculinity-define Keane's trajectory. And he concludes that, "Located at the crossroads between jazz and poetry, Shake's most significant achievement was ultimately a blurring of the boundaries between these two art forms." When he first arrived in London, he found work with "Caribbean Voices" on the ввС while at the same time developing a career as a jazz trumpetist. Nanton devotes a couple of detailed chapters to the music, the venues, the recordings, and the reviews of Keane's 1950s-6os performances, including his important contribution to the pioneering free form jazz scene in London and his seven years as a big-band musician based in Germany. There's a chapter on his poetry-one collection won the Casa de las Americas prize-including excerpts and reviews. Five appendices offer a number of Keane's poems, many previously unpublished. A discography completes this well-researched volume, written with seriousness and respect for a man whose life crossed with the whole panoply of West Indian intellectuals in London, from C.L.R.James to Linton Kwesi Johnson, and who played trumpet and flugelhorn alongside many of the greats of jazz.

Dancehall:A Reader on Jamaican Music and Culture, edited by Sonjah Stanley Niaah (Kingston: University of the West Indies Press, 2020, paper US\$49.00), examines the dominant Jamaican musical form of recent decades from the perspectives of history, sociology, musicology, performance studies, international studies, political science, and more. Though only twelve of the thirty-one chapters have not been previously published, this collection usefully brings together pioneering scholarship from the 198 os with emerging work on a music whose influence is now worldwide.

Lost Stitches: The Bostitch Legacy and My Crazy Jamaican Family, by Daniel Archer Melville with Rachel Manley (Kingston: Ian Randle, 2021, paper US\$ 30.00 ), tells the story of septuagenarian "Danny's" life as a wealthy, "white" Jamaican - polo aficionado, tourism impresario, promotor with Jimmy Buffet of the Jamaica Dogsled Team, and similar ventures - and inheritor (and dispenser) of his great-grandfather Thomas Briggs's fortune. Briggs, an upstanding New Englander, invented (among other things) the Bostitch stapler, which 
he produced at his Boston Wire Stitcher Company (Bostitch). After a fellow Jamaican, then living in New Zealand, visited and told Danny stories about his grandfather, who had married Brigg's daughter and settled with her in Jamaica, he enlisted his friend, Rachel Manley, daughter of Michael Manley and a wellknown writer, to help him explore his family history. The result is a chatty narrative in which he discovers, among other things, that his "whiteness" includes a Jamaican "browning" grandmother and a Jamaican Jewish great-grandmother. By the end, readers may have heard their fill about cockfighting, skeet shooting, and other pursuits of the leisure class but, as Melville argues, his life has been very Jamaican, from his attitudes about color to his love of music and sport.

Ángel G. ("Chuco") Quintero Rivera has brought together 5 oo pages of his writings (1978-2017) in La danza de la insurrección: Para una sociología de la música latinoamericana: textos reunidos (Buenos Aires: CLACSO, 202O, paper n.p. but also available as an open source pdf), filled with enthusiastic analyses not only of salsa but also politics and history. For Chuco, music is always embedded in its sociohistorical context and he writes in his thoroughly Boricua version of the British Cultural Studies tradition of Raymond Williams, E.P. Thompson, and E.J. Hobsbawm. This anthology provides an excellent introduction to the work of Puerto Rico's leading sociologist of music and dance.

Liminal Spaces: Migration and Women of the Guyanese Diaspora, edited by Grace Aneiza Ali (Cambridge: Open Book Publishers, 2020), opens by telling us that more Guyanese citizens live outside Guyana (in London, Toronto, New York ...) than in the country itself. And it quotes David Dabydeen, himself a migrant, writing that Guyana "is a disappearing nation" that has "to an unrivaled degree, exported its people." Ali, who teaches at the Tisch School of the Arts, NYU, and first curated two exhibitions on the theme of the book, states that "Instead of walls, I conceived Liminal Spaces as a visual exhibition on the page" and so it is. In her words, it "gathers fifteen women of Guyanese heritage to explore their relationship to migration through the literary and visual art forms of memoir, creative non-fiction, poetry, photography, curatorial and art essays." The book is at once poetic, documentary, and above all moving. You can download it, gratis, at: https://www.openbookpublishers.com//download/ book/1301

The bilingual publication, Sobre el estar comprometida con un lugar pequeño / On Being Committed to a Small Place (San José: TEOr/éTica, 2019, paper US\$20.00) presents a series of essays and interviews by Barbadian artist and activist Annalee Davis, who writes "in the context of Barbados, I am white. In Jamaica, I am a browning. In Trinidad, I am a red gyal ... Alternatively, I position myself as a white Creole woman." She is also an imaginative artist, and the book contains numerous color illustrations of artworks by her and oth- 
ers, many made on Fresh Milk, the former sugar plantation turned into a dairy farm and artists' residence that she calls home. The book addresses many of the challenges of cultural work in today's Caribbean - the struggles with uncaring politicians and technocrats, the lack of resources, the legacies of colonialismbut also the possibilities of nurturing young, local talent. The book is part of a larger Costa Rican-based project to build bridges between Central America and the Caribbean.

Une soirée haïtienne (Montreal QC: Éditions du CIDIHCA, 2020, US\$24.5O), edited by Thomas C. Spear, is an anthology of "the souls of the night," or in the words of Edwidge Danticat's blurb, "a polyphonic exploration of life, of creativity, and of Haitian dreams." Following on Spear's 2007 Une journée haïtienne, this collection consists of 30 short, previously unpublished tales of the night written by Haitians living at home or in the diaspora. Varied and imaginative, all solidly grounded in Haitian realities.

In One by One by One: Making a Small Difference Amid a Billion Problems (New York: HarperOne, 2020, cloth US\$27.99), neurologist Aaron Berkowitz guides us through a personal and medical adventure centered on a 23-yearold Haitian man with the largest brain tumor U.S. doctors had ever seen on a ст scan. The bulk of the book relates the author's role facing the bureaucratic and medical challenges of transporting the patient to Boston, getting him properly treated (and eventually housed) for many winter months, and eventually returning him for a slow and only partial recovery to Haiti. In a sense, the book is largely a paean to Partners in Health and medical anthropologist Paul Farmer, whose work in Haiti (and a number of other poor countries) has been so transformative. It is a story about trying to do good in a world without easy answers.

In 2020, Liverpool University Press published a trio of accessible, paperback introductions to the late (199os) thought of Édouard Glissant: The Baton Rouge Interviews (with Alexandre Leupin, translated by Kate M. Cooper), Treatise on the Whole-World (translated by Celia Britton), and Introduction to a Poetics of Diversity (translated by Celia Britton), each priced at US $\$ 25.95$. While The Interviews contains a good deal on medieval thought and literature, reflecting the interviewer's expertise, and the Treatise is an important if meandering exposition of the philosopher-poet's (antiglobalization) thoughts on the WholeWorld, the Introduction, which is based on a series of lectures, may be the clearest presentation of Glissant's views on creolization and language (including his insistence that Jamaican Creole is not really a creole language). Taken together, one gets an earful of Glissant's pronouncements on creolization, archipelagization, opacity, rhizomic identity, wandering, trace, and, above all, Relation.

In 2020, l' Institut du Tout-Monde in Paris began publishing a series of books, largely devoted to the work of its founder, Édouard Glissant. (It also published 
the first issue of its new journal, Les Cahiers du Tout-Monde, devoted to Glissantian studies.) Its initial books, available from amazon.fr, fnac.com, and other French booksellers, include: Édouard Glissant et Le Discours antillais: La source et le delta, edited by Sylvie Glissant, Loïc Céry, Hugues Azérad, Dominique Aurélia \& Laura Carvigan-Cassin (2020, paper $€ 28.50$ ) [Proceedings of a 201920 colloquium at the Institut du Tout-Monde/Cambridge University/Université des Antilles/Stanford University]; Saint-John Perse, Aimé Césaire, Édouard Glissant: Regards croisés, edited by Loïc Céry (2020, paper € 26.50 ) [Proceedings of a 2012 Institut du Tout-Monde colloquium]; Édouard Glissant, une traversée de l'esclavage. I-Étude critique: Premier tome, Rassembler les mémoires, edited by Loïc Céry (2020, paper n.p.); Édouard Glissant, une traversée de l'esclavage. IIÉtude critique: Second tome, Renverser les gouffres, edited by Loïc Céry (2020, paper n.p.); Édouard Glissant, une traversée de l'esclavage. III-Étude critique: Troisième tome, Anthologie commentée, edited by Loïc Céry (2020, paper n.p.); and Franz Fanon, Kateb Yacine, Édouard Glissant: Relation et indépendances, edited by Raphaël Lauro \& Catherine Delpech-Hellsten (2020, paper n.p.) [Proceedings of a 2015 Institut du Tout-Monde colloquium].

And another of Glissant's novels, Mahagony, published in French in 1987, has finally come out in English (Lincoln: University of Nebraska Press, 2020, paper US\$19.95). In a revealing 2018 Small Axe article about making this translation, Betsy Wing describes how she studied (and often argued) with Glissant in the late 1980s and early 199os, when he had just completed Mahagony, was working on his even more philosophical Poétique de la Relation, and had been reading Faulkner in French translation. She suggests that Mahagony is rooted in the idea of a venerable tree that, in its rings and other growth, keeps a record of the passage of time and history, and endures while ever changing. In the novel, she writes, "Glissant considers the culture of Martinique to be at death's door." And that he aims in it "to enable a doomed culture to bring itself back to life by bringing the still untamed past into the living present without seeking to domesticate/colonize it." The familiar Glissantian characters are here: Mathieu/Glissant, who narrates, the Longoués, Béluses, and Celats, the town of Lamentin ... Marronage, resistance, and relation are here. And opacité takes on an increasing importance, as does the notion of chaos. This polyphonic novel, ultimately about survival, is now presented in an excellent translation and is as good a place as any to plunge into the complex, always intriguing Tout-Monde of Glissant.

French Guiana: Memory Traces of the Penal Colony (Middletown CT: Wesleyan University Press, 2020, paper US\$15.95), with text by Patrick Chamoiseau and photographs by Rodolphe Hammadi, is Matt Reeck's translation of a brief 1994 book first published in a French government series on national his- 
toric monuments and sites. Chamoiseau's 23 pages of poetry and poetic prose, written in the wake of Eloge de la créolité, express familiar Glissant-derived notions - "unfathomable Memory traces ... broken, diffused, scattered" - to describe the bagne of Guyane, both the Isles de Salut (Devil's Island, et cetera) and the Camp de la Transportation in Saint-Laurent-du-Maroni. Hammadi's color photos are mainly documentary, showing the buildings as they remained, with encroaching vegetation. In 2011, Martinique's premier photographer JeanLuc de Laguarigue published his own photos of the bagne, using his friend Chamoiseau's text (which was by then out-of-print), in the oversized TracesMémoires du Bagne, better capturing the textures, colors, light and shadowsin "Bookshelf 2011" we called his photos of the bagne "paintings made with a lens." That book of photos would have made a stronger complement to Chamoiseau's evocative reflections.

Pierre Fatumbi Verger: Du regard détaché à la connaissance initiatique (Paris: Maisonneuve \& Larose, 2020, paper $€ 28$.oo), by French anthropologist Jérôme Souty, is a new edition (with some 80 new photographs) of a book first published in Paris in 2007, then in Brazilian Portuguese in 2011. A comprehensive analysis of Verger's half-century of work, primarily as photographer but also as amateur ethnographer, reluctant author, and initiate, it adds to the growing number of works on this intrepid explorer of the Black Atlantic, particularly of its interconnected religious worlds. The several sentences on Verger's Suriname visit are unfortunate, mentioning "Dutch Guiana (formerly Suriname)" and claiming that the Cottica "Djuka" (Okanisi) are of "Ashanti" origin. But Verger's nearly four decades based in Brazil, largely in Salvador (Bahia), and 17 (cumulative) years in West Africa (mainly Dahomey and Nigeria) yielded tens of thousands of often-stunning photos (including some of Haiti), the richest archive ever accumulated about the Black Atlantic.

Happily, artist and photographer Willem de Rooij has made the full suite of Verger's 257 Suriname images, shot over an eight-day visit in 1948, available in a handsome book, Pierre Verger in Suriname, edited by Willem de Rooij (Berlin: Walther König, 2020, paper US $\$ 76.66$ ). Verger and Swiss anthropologist Alfred Métraux stopped over on their way from Brazil to the Marbial Valley in Haiti, with the goal of their Suriname stay the Okanisi (Ndyuka) village of Wanhatti on the Cottica River that Métraux had visited the previous year. Verger's first 35 images (he labelled them "Hindou") are from Paramaribo, depicting the annual celebration of the arrival of the first transport bringing indentured workers from India in 1873 . These are followed by 42 images of the central market, and then by 46 street scenes. There are 113 images labeled "Wanhatti" depicting daily life in the village and 21 of a nighttime "Kromanti" (Kumanti) play. To get the captain's permission to take photos during that ceremony, Verger agreed to 
pay him with "my hammock, my mosquito net, my lantern, and my changes of clothes" and he afterward wrote that he was quite frightened by a "violent and brutal" possessed Kumanti man "who advanced towards me with a threatening air and threw rocks at me." Verger said that those photos were "the most risky pictures of my life." The book's 254 pages of glossy black and white photos are accompanied by essays by four scholars, including one on the Wanhatti photos by R.P.

In An Afro-Caribbean in the Nazi Era: From Papiamentu to German (independently published, 2020, paper US\$28.oo), Mary-Louise Romney-Schaab, an African American of Sint Maarten descent, reconstructs the life of her father, Lionel Ramsey, "a cricket player, a lumberjack, a gardener, a carpenter, a family man, a sailor, and a Dutch Sint Maartener." But her focus is on him as a multilingual, dignified Black man who survived five years of imprisonment during World War II, first in a series of internment camps in Italy, and then in Mauthausen, the notorious Nazi concentration camp in Austria. Based on oral history (once her aged father, after 40 years of silence about his wartime experiences agreed to speak), archival research, and travels in Europe, she traces his very Caribbean peregrinations-born in the D.R. while his father was doing seasonal toil in the canefields, later working for years as an electrician and carpenter in Curaçao, then in a refinery in Aruba, later shipping out on various merchant freighters until one sank in the Mediterranean and his captivity began. The starvation, the tortures, the gas chambers are all described in detail, and supplemented with photos. Thanks to his daughter, Lionel Ramsey stands as a proud, previously unsung Caribbean survivor of some of the worst Nazi atrocities.

Inward Outward, Critical Archival Engagements with Sounds and Films of Coloniality, edited by Rachel Somers Miles, Alana Osbourne, Eleni Tzialli, \& Esther Captain (https://doi.org/10.18146/inout2020), is the open-source publication of the proceedings of a 2020 symposium in the Netherlands, organized by the KITLV and the Netherlands Institute for Sound and Vision. Archivists, artists, researchers and others present papers on a variety of themes, from David Frohnapfel's "On Forgetting as a Queer Archival Practice" to Charissa Granger's "Looking Inward and Outward': Confronting Silence in an AfroCuraçaoan Archive," and from Tao Leigh Goffe's "On Being Prone in the Archive: Black British Erotic Power and Sexual Healing" to Deborah A. Thomas's "Form, Audience, Recognition: Transmediality and the Affects of Witnessing." A stimulating set of papers.

Any NWIG reader who assumes that the term "Latinx" is designed to avoid gendered language (Latino vs Latina) will have to be willing to enter a more nuanced, politically charged universe focused on race, class, and nationalism 
in order to follow the plea for greater inclusion of "the Latinx diasporic artistic community in New York City and beyond" in Arlene Dávila's Latinx Art: Artists, Markets, and Politics (Durham NC: Duke University Press, 2020, paper US\$25.95, with 17 full-color plates). Here, artists' residence history and political convictions come strongly into play and those who have not lived as racial minorities in the United States as well as those who choose to reject an American identity on political grounds fit Dávila's category poorly, which may explain why the major Puerto Rican artist Antonio Martorell, who combines his eclectic artistic creativity with pro-independence politics, does not even make the cut for the book's list of over 200 "artists everyone should know" (pp. 177-88).

José Parlá: It's Yours (Bologna, Italy: Damiani, 2020, cloth US\$100.00), published in conjunction with a solo exhibition in the Bronx Museum of the Arts, is a catalogue with beautifully reproduced color images of art by CubanAmerican painter José Parlá. It consists of excellent introductory essays by artist Henry Chalant (co-author of Subway Art) and Latinx artist Naiomy Guerrero, a lengthy interview with activist curator Manon Siome, and full-color plates of Parlás gigantic paintings on walls and canvasses. Parlá says that he grew up "in a Cuban home in Puerto Rico" but by age ten was painting on walls in Miami, later went to art school, was strongly influenced by hip hop, and traveled the world, from San Juan to Havana, London to Tokyo, Istanbul to Hong Kong; he now lives in Brooklyn. His paintings, which he calls "conceptual art," are a hybrid form of abstraction and urban realism, tied in closely with New York City subway art but also with neighborhoods "that the working class live in." He explains that the title painting of the exhibit, It's Yours, or The International Illegal Construct Against Indigenous People, means: "this city should belong to everyone."

Photostats Felix Gonzalez-Torres, edited by Richard Kraft \& Lisa Pearson (Catskill NY: Siglio, 2020, cloth US $\$ 36.00$ ), is an innovatively designed presentation of images created by the Cuban-born, Puerto-Rico-bred, American artist Felix Gonzalez-Torres (1957-96) at the height of the AIDs epidemic. Whether the book is read from one cover (with matte reproduction of the photostats) or flipped upside down and front to back (with glossy prints of the same photostats), the typeset words printed at various font sizes against a black background evoke a torrent of events, trends, and more: MTV 1983, Barbie Doll 1960, Willie Horton 1988, Streakers 1974, Pol Pot 1975, Freedom Summer 1964, Waterbeds 1971, H Bomb 1954 ... Essays by New York-based poet/art critic Ann Lauterbach (following the glossy plates) and Mexican-born poet Mónica de la Torre (following the matte plates) contextualize the images, evoking their relevance to issues and events of twenty-first-century concern. Layered events disrupting linear time, layered memories inviting new connections. 
Liquid Ecologies in Latin American and Caribbean Art, edited by Lisa Blackmore \& Liliana Gómez (New York: Routledge, 2020, cloth US\$155.00), is an intriguing and stimulating book that begins by noting that, "Affecting two thirds of river basins, the combined weight of the world's dams has literally shifted the axis of Earth and changed its speed of rotation, rewriting geohistory in the era of the Anthropocene." It is devoted to the complex relationship between rivers and power, as seen in art of every variety (from paintings, engravings, and maps to photos, video installations and film), produced all over the continent, from Argentina, Bolivia, Chile, and Peru up through the Indigenous Amazon and on to the Colombian Caribbean. Yet there is only onealbeit excellent—chapter not devoted to mainland South America, Elizabeth DeLoughrey and Tatiana Flores's "Submerged Bodies: The Tidalectics of Representability and the Sea in Caribbean Art," that takes us fully underwater, in our sea of dreams.

The Fruits of Empire: Art, Food, and the Politics of Race in the Age of American Expansion, by Shana Klein (Berkeley: University of California Press, 2020, cloth US\$65.00), with color illustrations, is largely devoted to national expansion, fruit cultivation, and the politicized depiction of fruit in the United States, moving from California grapes to Florida oranges and on to the ever-racialized watermelon. But there's an interesting chapter on bananas, which took off as a U.S. consumer product only after the Spanish-American war. By the 1920 s and '3os, on its "Great White Fleet"—100 white steamships owned by the United Fruit Company - tourists could book cruises "following the Conquerors through the Caribbean," according to one promotional brochure. In UFC's words, you could witness the "tonic of Yankee enterprise awakening" and civilizing "the swarthy savages." A final chapter takes readers to Hawaii for a pineapple dessert.

Rum-Rhum-Ron (Zürich:Alambic Books, 2020, cloth US\$29.0o), by Swiss bar owner and rum connoisseur Pascal Kählin with journalist Sina Bühler, begins with a brief history of sugar and rum production and then discusses more than 40 countries (most in the Caribbean), and nearly 100 distilleries, offering a paragraph description (and a personal evaluation) on each of the several hundred rums sampled. The occasional errors in maps (St. Martin/Sint Maarten is shown as two separate islands) or scale (calling Saint-Laurent-duMaroni a "village," though it is Guyane's second city with a population close to 6o,ooo), and so on, detracts little from the scope of the enterprise, which includes discussion of the rum of Nepal and the Philippines ("the third largest world market"). As far as our own expertise goes, the author's evaluations seem sound; he reveals which bottles have added postdistillation sugar, the types of stills each uses for distillation, the origins of casks used for aging, and 
much more. And he doesn't mince words: the taste of Rivers Royale Grenadian, for example, is compared to "lighter fluid, brush cleaner, or nail varnish remover," but he wins our hearts by noting that "J.M très vieux" from northern Martinique is "one of the very great rums" and that H.S.E.v.s.o.P. is "very accomplished." (N.B. At the 2020 International Sugarcane Spirits Awards, said to be the world's premier rum competition, H.S.E.V.s.O.P was awarded the gold medal and named: "Best Rum of the Caribbean.") Nonetheless, the very ambitiousness of the book makes for incompleteness-one wishes for more depth, both on the histories of particular distilleries and the choice of rums discussed.

Taste of the Islands: Culinary Adventures in a Caribbean Kitchen, by chefs (Jamaica-born) Hugh Sinclair and (Haiti-born) Cynthia Verna, with photos by (Jamaican American) TV producer Calibe Thompson (Gainesville: University Press of Florida, 2020, US\$28.00), is based on a PBS TV series of the same name. Filled with photos of both the dishes and brightly smiling participants in the project, it also provides a glossary of ingredients (explaining, for example, what an avocado is), and brief essays about some of the participants in the TV program. A few of the recipes seem unnecessarily complicated-do you really need 12 different ingredients for Bajan coucou/cuckoo? Lamming's mother, like Paule Marshall's, seems to have thought that cornmeal, okra, and water (with a bit of butter at the end) was enough - while others are worth a try.

Because of space restrictions, we chose not to solicit a full review of Baytoram Ramharack's Jung Bahadur Singh of Guyana (1886-1956): Politician, Ship Doctor, Labor Leader and Protector of Indians (San Juan, Trinidad: Chakra Publishing, 2019, paper US\$30.0o), but Lomarsh Roopnarine kindly offered the following assessment: "The book argues that Singh—born in the midst of the Indian indenture period (1886), who rose to be a member of the colonial legislature, a medical doctor, and a labor rights advocate — played a significant role in shaping British Guianese society in the first half of the twentieth century, though he remained an obscure figure even in Guyanese Indian historiography, overshadowed by his political and ideological nemesis, Cheddi Jagan."

A quick mention of the 108-page-long Precarious Lives: Black Seminoles and other Freedom Seekers in Florida Before the US Civil War, by A.A. Morgan, available gratis on the internet at www.aamorgan.com/Precarious-livesı.pdf. Beginning with an overview of Maroons in the Americas, then in North America, it quickly moves into an excellent survey of relations between formerly enslaved Africans and Indigenous peoples in the U.S. Southeast - the communities they built, the wars they fought, and the legacies they left. A useful summary of the available literature.

And another quick mention: Esclavage et MARRONNAGES: Refuser la condition servile à Bourbon (île de La Réunion) au XVIII ${ }^{e}$ siècle, edited by Gilles Pignon 


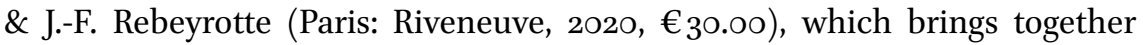
archaeologists, anthropologists, historians, artists, and others writing about maroons and their communities in the Indian Ocean, offers comparative information that will be useful to Caribbean scholars of slavery and resistance.

An extraordinary book that concerns the Caribbean at once peripherally and centrally: To Make Their Own Way in the World: The Enduring Legacy of the Zealy Daguerreotypes, edited by Ilisa Barbash, Molly Rogers \& Deborah Willis (Cambridge: Peabody Museum Press/Aperture, 2020, cloth US\$60.00). Focusing on daguerreotypes of seven enslaved men and women (identified as Alfred, Fassena, Jem, Renty and his daughter Delia, and Jack and his daughter Drana) made in 1850 South Carolina at the behest of zoology professor Louis Agassiz of Harvard, scholars (from senior Afro-Americanists Henry Louis Gates, Jr. and Evelyn Brooks Higgenbotham to several still working on their degrees) present varied analyses of these early attempts to support scientific racism with images. It is a book filled with images and words that make one weep and that range from Agassiz's photos of enslaved and Indigenous people in Manaus to the fraught ethical considerations involved in presenting these images. In our view, the issues are handled with dignity and thoughtfulness and raise questions for every scholar of race and slavery. To whom do these images belong? And who has a right to see them?

For readers who may not already know these terrific digital resources, we signal (1) archipelagos: a journal of Caribbean digital praxis, edited by Alex Gil \& Kaiama L. Glover-described as "a born-digital, peer-reviewed publication devoted to creative exploration, debate, and critical thinking about and through digital practices in contemporary scholarly and artistic work in and on the Caribbean," that has just published its fifth issue, and (2) The Digital Library of the Caribbean (dLOC), which celebrated its fifteenth anniversary in 2019 - a cooperative digital library for resources from and about the Caribbean and circum-Caribbean. The dLOC now has 6o partners in the United States, the Caribbean, Canada, Central and South America, and Europe. Its partner institutions provide access to digitized versions of Caribbean cultural, historical, and research materials currently held in archives, libraries, and private collections.

Finally, the authors of this Bookshelf (R P\&SP) have written a new, extensively revised edition of their 2003 book, Les Marrons. Entitled Les Marrons en Guyane, it takes account of nearly two decades of additional research and describes the profound changes that have taken place in the lives of the 100,000 Maroons living in Guyane. This new French-language edition - with more than 100 color images - is available free of charge. To download, go to: http://www .richandsally.net/les_marrons_en_guyane_.htm (An English language version, 
Maroons in Guyane: Past, Present, Future, will be published by the University of Georgia Press in early 2022).

Once again, Rosemarijn Hoefte has kindly provided an overview of recent Dutch-language books that may be of interest to our readers:

The past year turned out to be a sort of Anton de Kom year. In June it was announced that De Kom was chosen as one of the 50 topics in the Canon of Dutch History. The Canon is used in history teaching at the elementary and secondary levels in the Netherlands. It is the first time a person from the Caribbean has been included in the official Canon. Subsequently, the 16th edition of De Kom's Wijslaven van Suriname (Amsterdam: Atlas Contact, 2020, cloth $€ 20.00$ ) hit the bestsellers list. This new edition of the 1934 classic includes introductions by Mitchell Esajas, Tessa Leuwsha, and Duco van Oostrum. The latter's brief essay, situating Wij slaven in an international literary context, may be of particular interest to NWIG readers. It is based on Van Oostrum's article “'Someone Willing to Listen to Me': Anton de Kom's Wij Slaven van Suriname (1934) and the 'We' of Dutch Post-Colonial Literature in African American Literary Context," Dutch Crossing 44 (1) 2020, DOI: 10.1080/03096564.2020.1717193. In December listeners to a popular Dutch radio news program voted Wij slaven van Suriname the best nonfiction book of the year. And to top it off, Anton de Kom got his own chapter in Arend van Dam's De diamant van Banjarmasin (Amsterdam: CPNB, 202O, paper, free), the Dutch bookstores' gift to buyers of juvenile literature in the annual children's book week.

Dutch colonial history in general is in the spotlight. Four books on the colonial history of Amsterdam and Rotterdam and the catalogue of the exhibition on slavery in Amsterdam's Rijksmuseum will be treated in a review article in an upcoming issue of the NWIG (www.rijksmuseum.nl/whats-on/ exhibitions/slavery). The Nieuw Letterkundig Magazijn (xxxviII) has devoted its last issue of 2020 to slavery in the Dutch Empire with 13 contributions on Sri Lanka, the Netherlands East Indies, the Atlantic, the Dutch Caribbean, abolitionism, the use of postcolonial texts in schools, and, of course, Anton de Kom.

More history. Salomon Kroonenberg's De man van de berg: Friedrich Voltz (1828-1855), jonggestorven natuuronderzoeker in Suriname (Zutphen, the Netherlands: WalburgPers, 2020, paper $€ 24.99)$ is a well-written history of the German naturalist Friedrich Voltz, who set out to explore the Suriname interior in the hope of becoming as famous as his great examples Robert Schomburgk and Alexander von Humboldt. He was hired by the Dutch government to investigate the possible emigration of German colonists to Suriname, but his ambitions went well beyond this population issue. The book is based on Voltz's personal 
letters detailing his objectives, disputes with the Dutch government, expeditions, geographical descriptions, and botanic and geological annotations, and his scientific as well as social observations. Most people in Suriname know the Voltz Mountain; now we can learn about the man after whom this peak is named.

Miskend verleden: Hindostaanse boeren in Suriname 1880-1980 (Hilversum, the Netherlands: Verloren, 2020, cloth €29.00), by Ruben Gowricharn, relates the neglected history of Hindustani smallholders in Suriname. Gowricharn has gathered an admirable amount of data, but in many instances the detail is overwhelming. Ultimately, the struggling farmers remain faceless, as they have been for more than a century. Oog in oog met Paramaribo: Verhalen over het herinneringserfgoed (Volendam, the Netherlands: LM Publishers, 2020, cloth $€ 24.5^{\circ}$ ) is Eric Kastelein's well-produced encyclopedic overview of photographs and stories of Paramaribo's memorial heritage varying from statues to plaques to commemorative trees. It is a narrative about politics, promises, plans, openings, and neglect. The book is divided into 11 thematic chapters; politics and culture, science, and sport are the two largest sections. More than 100 sites are included; the oldest dates from 1813, the most recent from 2018. Erwin de Vries is the most productive artist, with 23 works. I counted 42 monuments et cetera that were erected in the twenty-first century. Kastelein doesn't analyze this boom and the function of memorial sites as a function of nation building. Surprisingly, the highly relevant article by Peter Meel on monuments and nationalism in Suriname (NWIG 72, 1998) is not included in the bibliography, but that is only a minor blemish on this engaging publication.

Moving on to two publications on art. The attractive Black in Rembrandt's Time (Zwolle, the Netherlands: wвоокs, 2020, paper € 24.95) includes 95 illustrations in color, about half of them full-page, depicting Black people in seventeenth-century works of art. Editors Elmer Kolfin and Epco Runia, and contributors Mark Ponte, Stephanie Archangel, and David de Witt, show that even when the Dutch Republic became increasingly involved in transatlantic commerce, the later stereotypes of Black people had not yet become dominant. Rembrandt and his contemporaries portrayed individual Black models in their immediate vicinity. Around 1650 there existed a small free Black community in Rembrandt's neighborhood; the growth of this community is reflected in the Black presence in paintings. Somehow René Tosari: Diversity is Power (Heijningen, the Netherlands: Jap Sam Books, 2018, paper € 29.50), edited by Rob Perrée and Priscilla Tosari, slipped through the cracks earlier. This striking volume with more than 100 full color plates discusses the work of visual artist René Tosari (b. 1948, Paramaribo), who divided his time between Suriname and the Netherlands, but now has returned to his country of birth. Perrée, Steve 
Ammersingh, and Marieke Visser discuss Tosari's work, education, and political activism, especially supporting Suriname's military regime in the 1980s, and his instructional skills guiding young students in both Paramaribo and Amsterdam. The book includes a timeline by Priscilla Tosari and a foreword by Chandra van Binnendijk.

Next up is (auto)biographical writing. Kan niet bestaat niet: Het kleurrijke leven van Otmar Buyne by Roy Khemradj (Volendam, the Netherlands: LM Publishers, 2019, paper $€ 19.50$ ) is not your typical biography as it reveals little about the private life of the protagonist. Otmar Buyne (b. 1929) is a multitalented psychiatrist and neurologist, athlete, storyteller, poet, cook, and writer of culinary books, who has lived, studied, and worked in Suriname and the Netherlands. The book is slightly overflattering, but gives some interesting insights into working-class, late colonial Paramaribo, including its blatant racism. In 1980 Buyne was director of the military hospital in Suriname's capital, and his account of the coup and the torture of politicians is blood curdling. Nog ver van een waarachtige democratie: Een politieke en staatsrechtelijke beschouwing van de Republiek Suriname by Gerold R. Sewcharan \& Iwan Brave (Volendam, the Netherlands: LM Publishers, 2020, paper $€ 15.00$ ) is a collection of 22 previously published articles and speeches by lawyer Sewcharan, each one introduced by journalist Brave. The main theme is the relationship between justice/law, democracy, and development. Sewcharan's dissection of the flaws in the country's political and legal systems, which go beyond the twenty-first century machinations, offers no fundamentally new insights, but does give some interesting observations about political and legal processes in Suriname. His focus is on the importance of integrity, professionalism, and accountability in both domains. Sewcharan's political party, PRO, did not gain any seats in the May 2020 elections, as it was crushed in what was essentially a referendum on convicted murderer Desi Bouterse. The winner was the leader of the opposition, Chan Santokhi, to the detriment of new political voices.

Raoul de Jong's Jaguarman: Mijn vader, zijn vader en andere Surinaamse helden (Amsterdam: De Bezige Bij, 2020, paper $€$ 22.99) seems at first sight like one of those dime-a-dozen publications by a Dutch-Surinamese person discovering his roots in the Caribbean. But after only one or two pages you realize this book belongs in a different league. A few lines can't do justice to a fascinating story by a very gifted author. In ten letters he addresses his forefather, the jaguar man, describing his three-month journey of discovery in Suriname and intermixing it with his experience undergoing a week-long Winti ritual in his hometown of Rotterdam, after his return from Suriname. It is an irresistible mix of history (starring Anton de Kom once more), literature, magical thinking, fairy tales, and much, much more. 
Het verbrande huis: Een Surinaamse familiegeschiedenis by Bodil de la Parra (Amsterdam: Lebowski, 2020, paper €22.99) is also so well written that it is almost unputdownable. Actress and playwright Bodil, daughter of film director Pim de la Parra (Wan Pipel), sketches a loving, sparkling, and melancholic portrait of the De la Parra family. She first visited Suriname when she was six and has returned frequently for professional gigs and family visits. The book starts and concludes with the burning down of the family mansion in downtown Paramaribo in 2012. De la Parra's first book is based on her theater performance with the same title.

One of the better nonfiction reads of this year is Pitou van Dijck's Naar het eind van de Amazone (Volendam, the Netherlands: LM Publishers, 2020, paper $€ 24.50$ ). This travelogue often reads like a novel. Dutch economist Van Dijck and Brazilian mathematical biologist Cristina (no last name) travel by car from Cuzco to Manaus, her hometown. He then continues by ship from Manaus to Iquitos (Peru), flies back to Manaus, and jumps into the car again to drive to Guyana and Suriname. There he goes from Paramaribo to the southern border, near Brazil. The goal of this adventure is to find out what is happening in and to the Amazon: who has an interest in building and financing roads? Is it possible to understand and control in advance the consequences of infrastructural projects and all the developments they stimulate? This dismal story is about local and international politics, research reports, business interests, and disappearing plans and population questionnaires. And about history, ecology, biology, and economy. While reading I was constantly checking maps on my iPad to follow the traveler(s) - most of the maps in the book are of too poor quality to be of help. Recommended, not only for Caribbeanists and Latin Americanists.

The only novel in this year's overview, Tessa Leuwsha's Plantage Wildlust (Amsterdam: Atlas Contact, 2020, paper $€$ 19.99), is partially based on a family archive, including reports, letters, and photos, relating life at Surinamese coffee plantation Peperpot in the early twentieth century. Two of the book's protagonists, Alma and Rambaroos, are modelled after Amalia Christina Ramer and Rhambharosay Kishun Misser, whose photo adorns the cover. The two clueless Dutch protagonists are fictional. Plantage Wildlust sketches a Caribbean history of exploitation, misunderstanding, homesickness, and ethnic and social tensions.

More literature. Het andere postkoloniale oog: Onbekende kanten van de Nederlandse (post)koloniale literatuur, edited by Michiel van Kempen (Hilversum, the Netherlands; Verloren, 2020, paper $€ 32.00$ ), is the outcome of a seminar in 2019 celebrating the 12-and-a-half-year anniversary (a strange Dutch custom) of Van Kempen's Chair in Dutch-Caribbean Literature at the University of Am- 
sterdam. The topic of (post)colonial literature is not enough to tie this collection of new and recycled essays and presentations together, but it includes a number of interesting chapters on, for example, Rosey Pool and Nola Hatterman (by Lonneke Geerlings \& Ellen de Vries) and Astrid Roemer (by Yra van Dijk).

This year only one book on Curaçao, or any of the other Caribbean islands in the Kingdom of the Netherlands, crossed my desk. In Hitte en heimwee: Brieven en berichten van passanten op Curaçao 1910-1930 (Amsterdam: Uitgeverij Panchaud, 2020, paper $€ 24.90$ ), Peter Frederiks has collected writings by six Dutch migrants in the first half of the twentieth century. They include a judge and his wife, an employee of an oil company and his wife, and a female and a male missionary. In their letters and newspaper articles (by judge Bastiaan de Gaay Fortman, who also contributed to the WIG, and Father Jan Paul Delgeur) they sketch life on the island through thoroughly Dutch eyes. Returning themes are the lack of knowledge about Curaçaoan society and culture, the island's aridness and the lack of potable water, the climate, insects, illnesses, and the exuberant parties. Except for the missionaries, these transients left their social bubble only occasionally. The book gives a vivid impression of Dutch views on late colonial life on an island that was on the brink of profound socioeconomic transformations.

Thank you Rosemarijn! We end this year's Bookshelf by listing information on titles that we have noticed but neither examined nor requested for review -in some cases because their Caribbean content is restricted to a chapter or two, in others because they didn't seem sufficiently compelling given NWIG space limitations, or for a variety of other reasons. Together, they testify to the large number of books being published that at least touch on the Caribbean.

Who Makes Social Policy?: Social Networks and the Political Economy of Social Policy in Latin America and the Caribbean (Washington DC: The World Bank, 2020, paper US\$39.95)

Abortion in Latin America and the Caribbean: The Legal Impact of the American Convention on Human Rights, by Ligia De Jesús Castaldi (South Bend IN: University of Notre Dame Press, 2020, cloth US\$75.00)

Gendered Responses to Male Offending in Barbados: Patriarchal Perceptions and Their Effect on Offender Treatment, by Corin Bailey (London: Routledge, 2020, cloth US\$60.00)

The Price of Poverty: An Analysis of Jamaican Gang Development, by Asheka Jackson (Basingstoke. U.K.: Palgrave Macmillan, 2020, cloth US\$99.99)

Diversity and Inclusion in Latin American and Caribbean Workplaces: Experiences, 
Opportunities, and Challenges, edited by Carlos Tasso Eira de Aquino \& Ronald R. Rojas (Basingstoke, U.K.: Palgrave Macmillan, 2020, cloth US\$119.99)

The Judicial Committee of the Privy Council and the Caribbean Court of Justice: Navigating Independence and Changing Political Environments, by Harold A. Young (Lanham MD: Lexington Books, 2020, cloth US\$ 90.0o)

The First East Indians to Trinidad: Captain Cubitt Sparkhall Rundle and the Fatel Rozack, by Dennison Moore (independently published, 2020, paper US\$21.95)

Rochester: A Thornfield Story:Based on Jane Eyre and Wide Sargasso Sea, by J.L. Niemann

(Conneaut Lake PA: Page Publishing, 2019, paper US\$ 22.95) [self-published novel]

Latinx Literature Now: Between Evanescence and Event, by Ricardo L. Ortiz (Basingstoke, U.K.: Palgrave Macmillan, 2019, cloth US\$59.99)

The Business of Leisure: Tourism History in Latin America and the Caribbean, edited by Andrew Grant Wood (Lincoln: University of Nebraska Press, 2021, cloth US\$99.0o) [only two chapters on the Caribbean-Cuba and the Dominican Republic]

French Connections: Cultural Mobility in North America and the Atlantic World, 16001875, edited by Andrew N. Wegmann \& Robert Englebert (Baton Rouge: Louisiana State University Press, 2020, cloth US\$50.00)

The Barbados Community College Experience: Leading the Anglophone Caribbean in a Global Movement, by Vivienne Roberts (Kingston: University of the West Indies Press, 2020, paper US\$40.00)

Education and Development: Policy Imperatives for Jamaica and the Caribbean, by Canute S. Thompson (Kingston: University of the West Indies Press, 2020, paper US\$30.00)

Political Communication Strategies in Post-Independence Jamaica, 1972-2006, by Floyd E. Morris (Kingston: University of the West Indies Press, 2020, paper US\$35.00)

Compatriotas: Exilio y retorno de Luis Muñoz Marín, by Pablo J. Hernández Rivera (Ponce, Puerto Rico: Fundación Rafael Hernández Colón, 2020, paper US\$19.99)

Caribbean Writers on Teaching Literature, edited by Lorna Down \& Thelma Baker (Kingston: University of the West Indies Press, 2020, paper US\$45.00) [contributors include Thelma Baker, Edward Baugh, Victor Chang, Carolyn Cooper, Norval Edwards, Brian Heap, Kelly Baker Josephs, Mark McWatt, Mervyn Morris, Sharon Phillips, Velma Pollard, Sandra Robinson, Samuel Soyer, Aisha Spencer, Maureen Warner-Lewis, David Williams, and Ann-Marie Wilmot]

Decolonization of Psychiatry in Jamaica: Madnificent Irations, by Frederick W. Hickling (Cham, Switzerland: Palgrave Macmillan, 2021, cloth US\$109.0o)

Belonging in Brixton: An Ethnography of Migrant West Indian Elders in Brixton, London, by Audrey Allwood (Cham, Switzerland: Palgrave Macmillan, 2021, cloth US\$ 89.99) Re-imagining Communication in Africa and the Caribbean: Global South Issues in Media, Culture and Technology, edited by Hopeton S. Dunn, Dumisani Moyo, William O. Lesitaokana \& Shanade Bianca Barnabas (Cham, Switzerland: Palgrave Macmillan, 2021, cloth US\$119.99) 
Fidel in the Cuban Socialist Revolution: Understanding the Cuban Revolution (1959-1961), by Fidel Castro, edited by José Bell Lara (Chicago: Haymarket, 2020, paper US\$28.00)

'Membering Austin Clarke: A Writer, A Life, edited by Paul Barrett (Waterloo ON: Wilfrid Laurier University Press, 2020, paper US\$39.99)

Advances in Contact Linguistics: In Honour of Pieter Muysken, edited by Norval Smith, Tonjes Veenstra \& Enoch Oladé Aboh (Amsterdam: John Benjamins, 202O, cloth US\$158.00) [includes several chapters on Caribbean creoles: Virgin Island Dutch Creole, Sranan, and a consideration of whether creoles are a special type of language]

Gendered empire. Intersectional perspective on Dutch post/colonial narratives, edited by Nancy Jouwe (Hilversum: Yearbook of Women's History/Jaarboek voor Vrouwengeschiedenis 39, 2020, paper $€ 23.00$ ) [Rosemarijn Hoefte tells us that most articles are on the East Indies, but there is one by Gloria Wekker, "How Families Navigate Empire" as well as an interview with Glenda Martinus and her son Quincy Gario (a well-known activist in the movement against Zwarte Piet) on Trinta di Mei in Curaçao.] 